\title{
Interspecific Hybridizations in Ornamental Flowering Cherries Validated by Simple Sequence Repeat Analysis
}

\author{
Margaret Pooler ${ }^{1}$ and Hongmei Ma \\ USDA-ARS, U.S. National Arboretum, 10300 Baltimore Avenue, Building 010A, Beltsville, MD 20705
}

\begin{abstract}
Additional INDEX wORDs. simple sequence repeat, molecular markers, plant breeding, Prunus
Abstract. Flowering cherries belong to the genus Prunus, consisting primarily of species native to Asia. Despite the popularity of ornamental cherry trees in the landscape, most ornamental Prunus planted in the United States are derived from a limited genetic base of Japanese flowering cherry taxa. Controlled crosses among flowering cherry species carried out over the past 30 years at the U.S. National Arboretum have resulted in the creation of interspecific hybrids among many of these diverse taxa. We used simple sequence repeat (SSR) markers to verify 73 of 84 putative hybrids created from 43 crosses representing 20 parental taxa. All verified hybrids were within the same section (Cerasus or Laurocerasus in the subgenus Cerasus) with no verified hybrids between sections.
\end{abstract}

Ornamental flowering cherry trees are popular plants for street, commercial, and residential landscapes. Grown primarily for their spring bloom, flowering cherries have been in the United States since the mid-1850s (Faust and Suranyi, 1997), and they gained in popularity after the historic Tidal Basin cherries were planted in Washington, DC, in 1912. Over 1.2 million plants are sold wholesale each year at a value of more than \$32 million [U.S. Department of Agriculture (USDA), 2010]. Despite the large number of Prunus species with diverse origins and ornamental traits, the most widely cultivated flowering cherry trees planted in the United States represent only a few species, primarily $P$. serrulata, $P$. subhirtella, and $P$. yedoensis. The U.S. National Arboretum has an ongoing breeding program aimed at broadening this genetic base by developing new cultivars of flowering cherries with disease and pest resistance, tolerance to environmental stresses, and superior ornamental characteristics. Hundreds of interspecific Prunus hybridizations have been carried out at the U.S. National Arboretum over the past 30 years. Verifying whether these resulting plants are true hybrids is complicated by the fact that morphological characteristics such as flower, leaf, or bark traits are quite variable and heterogeneous among the various taxa and are therefore often inadequate for confirming hybridity. The objective of this study was to verify the pedigree of a number of the putative interspecific hybrids created at the U.S. National Arboretum.

\section{Materials and Methods}

Plant materials and hybridizations. Prumus parent taxa and hybrids used in this study are listed in Table 1. Controlled crosses were performed in the field during the year indicated. Crosses were made by covering clusters of unopened flower buds with a pollination bag and then hand-pollinating flowers as they opened using a camel hair paintbrush. In cases in which the

Received for publication 8 Jan. 2013. Accepted for publication 4 Feb. 2013. ${ }^{1}$ Corresponding author. E-mail: margaret.pooler@ars.usda.gov. pollen parent bloomed before the seed parent, anthers were collected from the pollen donor just before flower opening and allowed to dehisce in gelatin capsules which were stored in paper coin envelopes in the refrigerator before use. In most cases, the seed parent was emasculated before pollination. Generally, at least 50 flowers were pollinated for each cross, and some crosses were attempted over several years. As seeds developed, they were covered with mesh bags to prevent loss and harvested when ripe. Seeds were cleaned of fruit, sown in flats containing a soilless potting mix (milled sphagnum and course sand, 1:1), and then moist-stratified for three months in the dark at $4{ }^{\circ} \mathrm{C}$. After stratification, flats were placed in a $21^{\circ} \mathrm{C}$ greenhouse for seed germination. Seedlings were transplanted to containers and ultimately to the field.

DNA EXTRACTION, SIMPLE SEQUENCE REPEAT PRIMERS, AND POLYMERASE CHAIN REACTIONS. Total genomic DNA was extracted using the rapid one-step extraction (ROSE) method as described previously (Ma et al., 2009; Steiner et al., 1995), except that frozen leaves were ground in $200 \mu \mathrm{L}$ ROSE buffer using lysing matrix tubes in a FastPrep machine (MP Biomedicals, Santa Ana, CA). Seven SSR primer pairs developed for other (non-ornamental) Prunus species were used to amplify the following loci (Table 2): GA59, GA77, CPDCT006, СPDCT033, pchgms3, UDP96001, and UDP97-403. SSR primer synthesis, reactions, and data collection were as described previously (Ma et al., 2009) with fluorescently labeled polymerase chain reaction (PCR) product sizes determined by analysis using an $\mathrm{ABI} 310$ Genetic Analyzer (Applied Biosystems, Foster City, CA) using GeneScan software Version 3.1.2 (Applied Biosystems). Genotyper software Version 2.5.2 (Applied Biosystems) was used to process and view GeneScan-sized peaks.

\section{Results and Discussion}

In this study, 84 plants representing 43 interspecific hybrids using $\approx 20$ taxa of ornamental flowering cherry were evaluated with SSR markers to verify putative hybrids; 73 of these 84 plants could be verified as hybrids (Table 1). In some cases, these hybrids represent a sampling of a larger population; in 
Table 1. Cross, parents, and simple sequence repeat (SSR) profiles of Prunus parents and hybrids tested in this study. ${ }^{\mathrm{z}}$

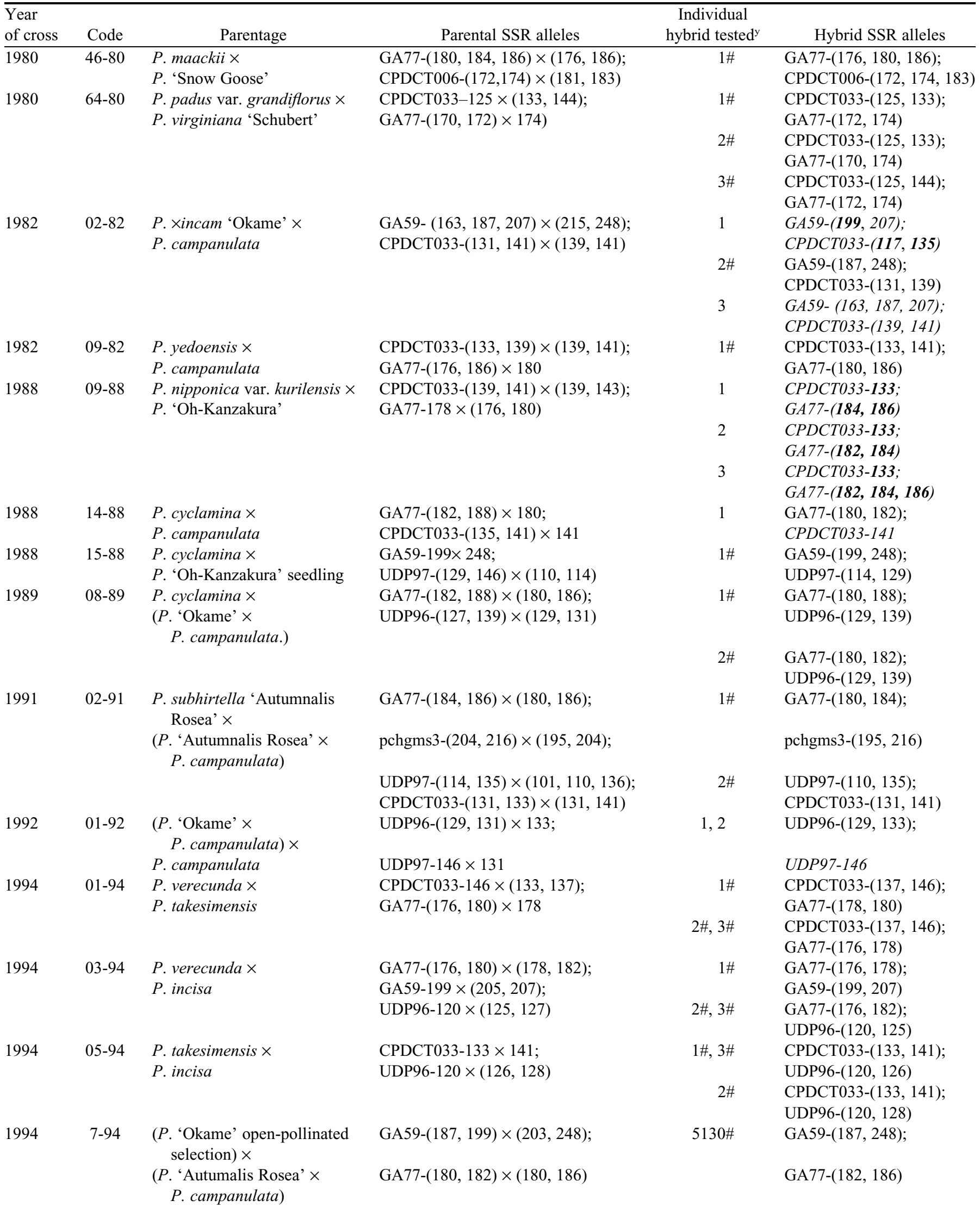


Table 1. Continued.

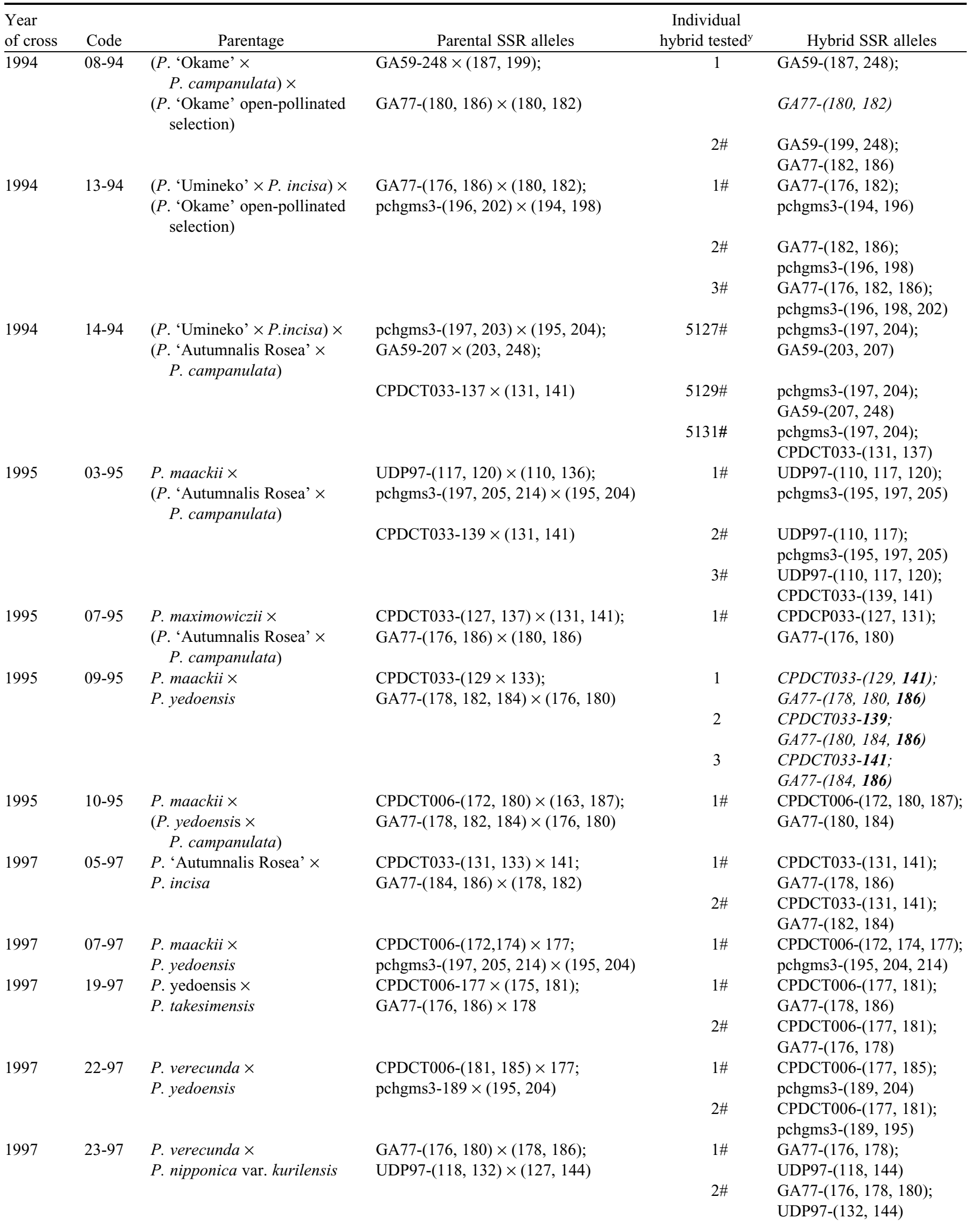

Continued next page 
Table 1. Continued.

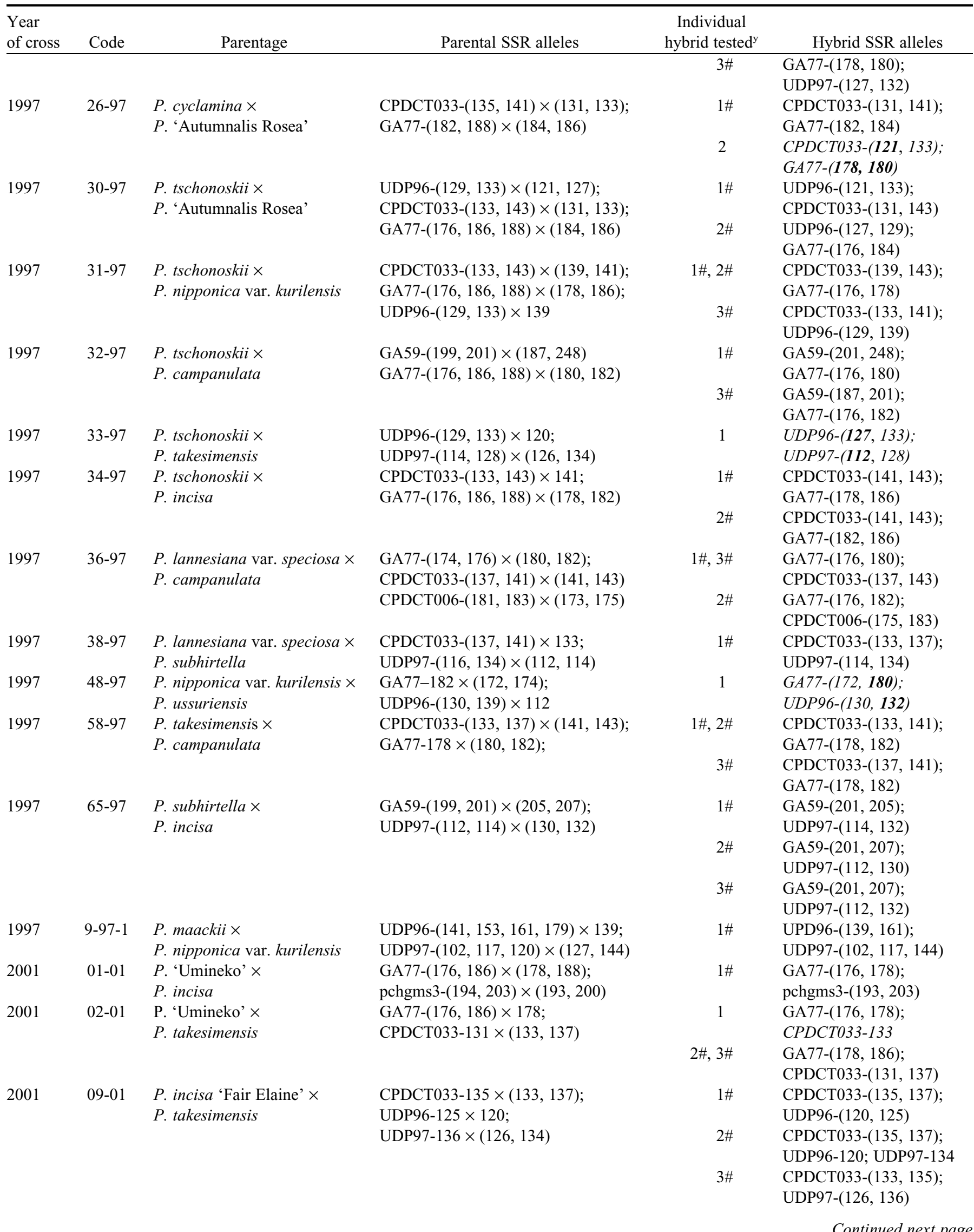


Table 1. Continued.

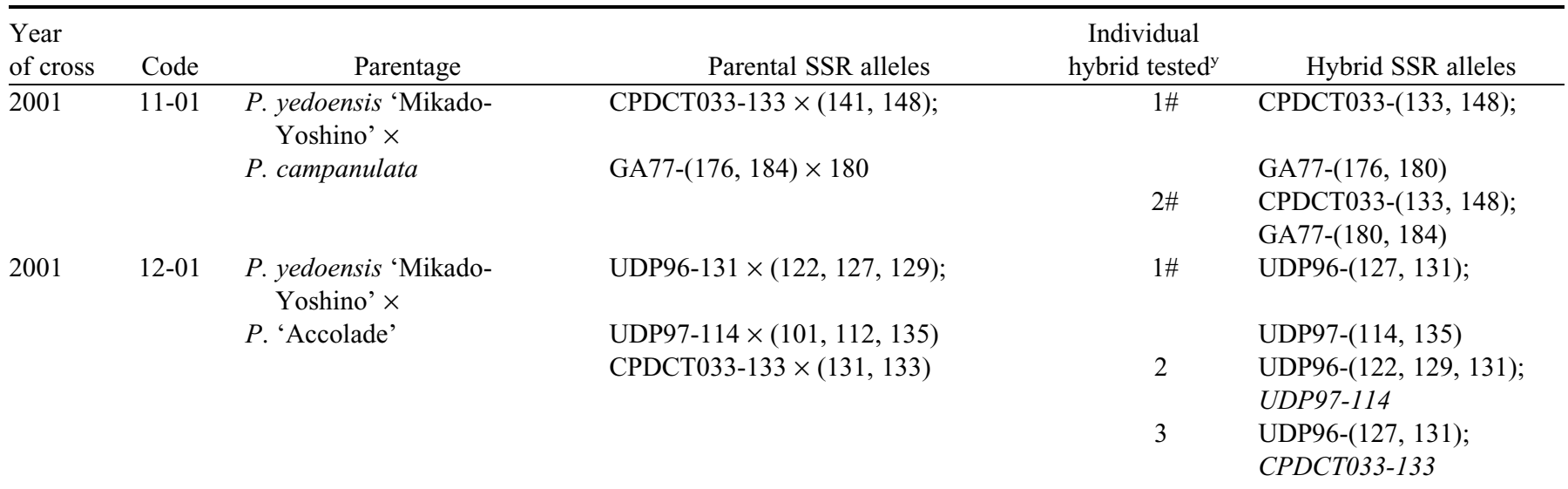

${ }^{\mathrm{z}}$ Markers in regular type confirm hybrid origin; markers highlighted in italics could not be used to confirm hybrid origin; markers in bold indicate non-parental bands. Species designations of cultivars (when known) are given only at the first use of the name. Different genotypes of the same species may have been used in different crosses, leading to different SSR allele profiles for the same parental species.

y "\#” beside the hybrid plant number indicates a confirmed hybrid.

Table 2. Simple sequence repeat (SSR) marker name, linkage group (Jung et al., 2008), annealing temperature and reference of the seven SSR primer pairs used to verify Prunus hybrids in this study.

\begin{tabular}{lccl}
\hline SSR marker & $\begin{array}{c}\text { Linkage } \\
\text { group }\end{array}$ & $\begin{array}{c}\text { Annealing } \\
\text { temp }\left({ }^{\circ} \mathrm{C}\right)\end{array}$ & \multicolumn{1}{c}{ Reference } \\
\hline GA59 & 1 & 55 & Cantini et al., 2001 \\
GA77 & 4 & 55 & Bliss et al., 2002 \\
CPDCT006 & 6 & 55 & Mnejja et al., 2005 \\
CPDCT033 & 3 & 55 & Mnejja et al., 2005 \\
pchgms3 & 1 & 55 & Sosinski et al., 2000 \\
UDP96-001 & 6 & 55 & Cipriani et al., 1999 \\
UDP97-403 & 3 & 55 & Cipriani et al., 1999 \\
\hline
\end{tabular}

other cases, only a few progeny resulted from the cross. We considered plants to be confirmed hybrids if at least two SSR markers from each parent were observed in the progeny (Fig. 1). Because of the proximity of different Prunus species in our research nurseries, it is possible that paternal bands could have come from another species that share the same allele as the pollen parent used in the cross. However, this contamination is likely to be rare because flowers were protected with pollination bags to exclude insect pollinators.

All hybrid combinations tested revealed confirmed hybrids for at least one plant from that cross with the exception of $P$. nipponica var. kurilensis $\times P$. kanzakura 'Oh-Kanzakura' (1988), which showed non-parental bands in all progeny; and $P$. maackii $\times P$. yedoensis (1995), $P$. tschonoskii $\times P$. takesimensis (1997), and P. nipponica var. kurilensis $\times P$. ussuriensis (1997), which all showed non-parental bands as well as maternally inherited bands, but no paternally inherited bands. Non-parental bands were observed with most primer sets used (Table 2; Fig. 2), indicating that the non-parental bands are unlikely to be an artifact of a specific primer amplification. Previous studies (Ma et al., 2009) using four of these SSR primers (CPDCT033, GA59, GA77, and pchgms3) also showed occasional non-parental bands but revealed that these primers followed expected inheritance in ornamental Prunus and could therefore be useful in hybrid verification. Plants that could not be conclusively verified as hybrids may be open-pollinated or possibly self-pollinated progeny.
Taxa used for crosses were chosen based on phenotypic traits as well as our desire to create novel interspecific hybrids with underused germplasm. P. maackii (Manchurian or Amur cherry) is a cold-hardy species with ornamental exfoliating bark and a fast growth rate. $P$. campanulata (Taiwan cherry) has very dark pink flowers and an early bloom time but is only hardy to USDA Hardiness Zone 8 (Krussmann, 1984; USDA, 2012b). P. nipponica var. kurilensis, and to a lesser extent $P$. incisa, have a short, shrubby habit that could be valuable in creating cultivars for smaller landscapes. The $P$. takesimensis germplasm that we used was collected from a site with wet soil so may contribute tolerance to wet sites. $P$. 'Autumnalis Rosea' has a unique spring and fall bloom cycle. $P$. verecunda is a larger, vigorous species with a late bloom date (Flower Association of Japan, 1982) that could be useful in prolonging the spring bloom display. Other taxa such as $P$. yedoensis, 'Snow Goose', 'Okame', and P. cyclamina were used primarily for superior flower traits.

Generally, interspecific hybridizations in Prunus are relatively easy to achieve. We have reported confirmed interspecific ornamental cherry hybrids previously (Ma et al., 2009; Pooler et al., 2012), as have others (Ingram, 1970; Kuitert, 1999; Ohta et al., 2007; Tsuruta et al., 2012). In fact, many cultivars are the result of interspecific hybridizations [e.g., Prunus Xincam 'Okame' (Olsen and Whittemore, 2009)]. Spontaneous hybridization between native and cultivated species as well as naturalization of species and selections beyond their native ranges has led to some of the confusion as to the taxonomic and nomenclatural treatment of the ornamental Prunus (Jefferson and Wain, 1984; Notcutt and Notcutt, 1935). Classification is further complicated by the fact that morphological characters that were used to classify Prunus species previously such as inflorescence type have evolved independently and repeatedly (Bortiri et al., 2006; Liu et al., 2012). Hence, some of the "wide" hybrids between members of different sections or subgenera are less surprising as the taxonomic issues are resolved and we discover that these taxa are not as distantly related as previously thought. For example, $P$. maackii was thought to be a member of the subgenus Padus based on floral morphology (e.g., Rehder, 1940); however, more recent molecular studies support its closer association 


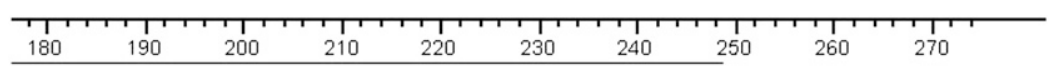

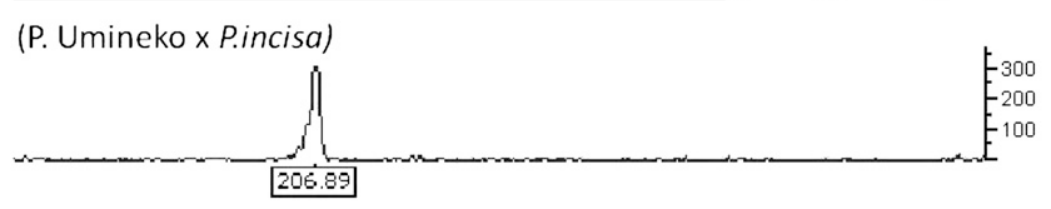

(P. 'Autumnalis Rosea' x P. campanulata)

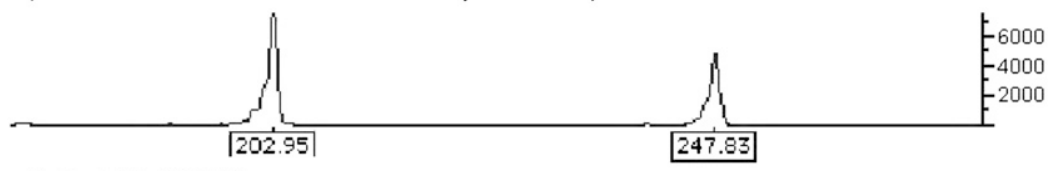

Hybrid 1 (5127)

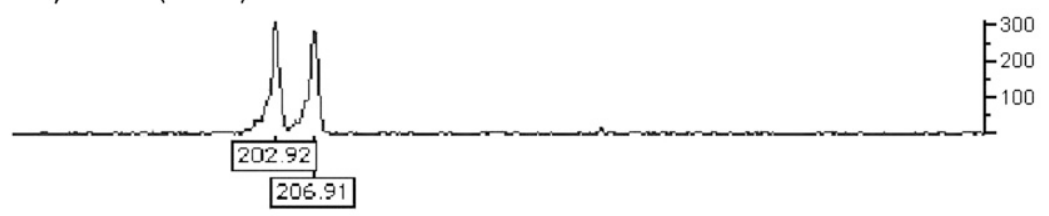

Hybrid 2 (5129)

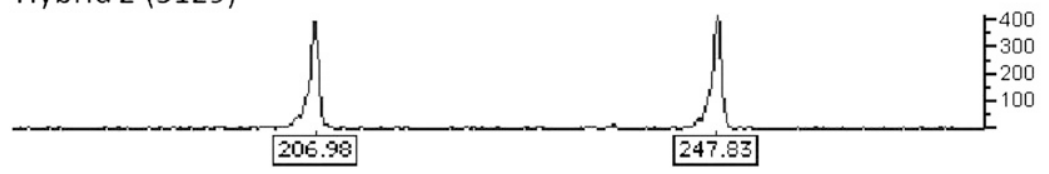

Fig. 1. ABI Genotyper (Applied Biosystems, Foster City, CA) output of simple sequence repeat (SSR) profile for primer GA59 of parents and progeny of 1994 Prunus cross [(Prunus 'Umineko' $\times$ $P$. incisa $) \times(P$. 'Autumnalis Rosea' $\times P$. campanulata $)$ ] supporting hybridity.

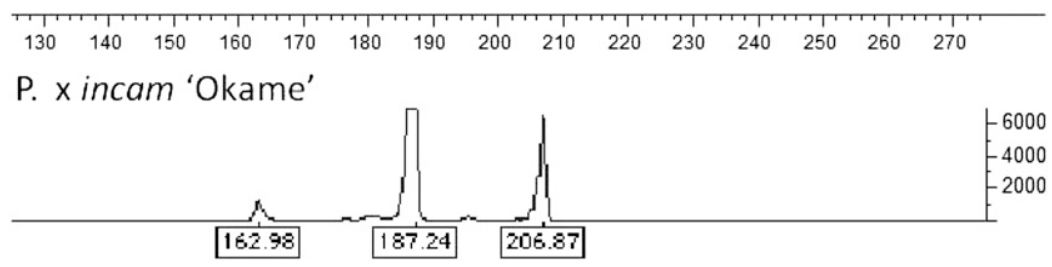

\section{P. campanulata}

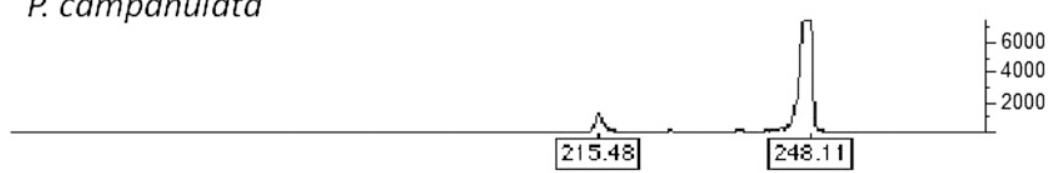

Hybrid 1

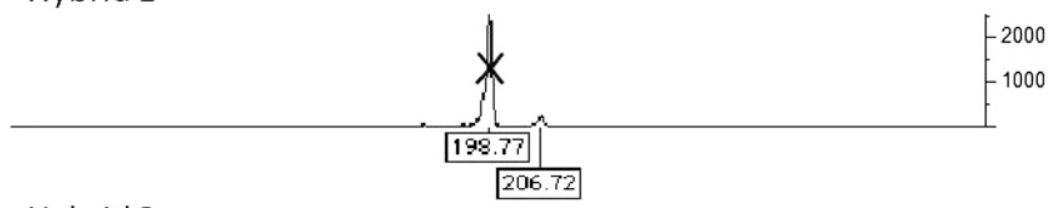

Hybrid 2

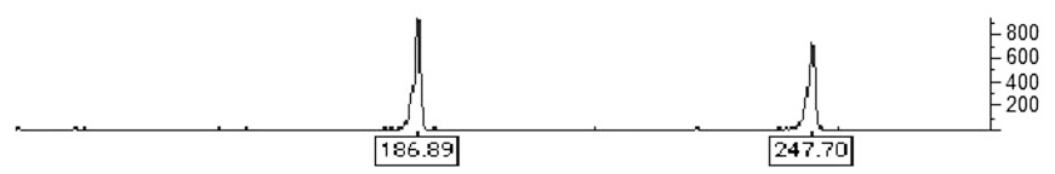

Fig. 2. ABI Genotyper (Applied Biosystems, Foster City, CA) output of simple sequence repeat (SSR) profile for primer pair GA59 of parents and progeny of 1982 Prunus cross (Prunus $\times$ incam 'Okame' $\times$ $P$. campanulata) showing parental and non-parental bands (marked with " $\mathrm{x}$ ") in the progeny.

with other ornamental taxa in subgenus Cerasus section Cerasus (Bortiri et al., 2001, 2002; Lee and Wen, 2001). The ease with which we have been able to create interspecific hybrids between $P$. maackii and other members of section Cerasus further supports this classification.

The species used in this study all fall within the subgenus Cerasus section Cerasus (USDA, 2012a), with the exception of $P$. padus and $P$. virginiana. Crosses between these two species (subgenus Cerasus, section Laurocerasus) resulted in confirmed hybrids (Table 1). When used as a parent in further crosses with species from section Cerasus, this hybrid has not resulted in confirmed viable progeny. We have also attempted crosses between other members of section Laurocerasus (including $P$. buergeriana, $P$. grayana, $P$. laurocerasus, $P$. lusitanica, $P$. padus, and $P$. virginiana) and species in section Cerasus with no confirmed hybrids. Other attempted wide hybrids included crosses between P. mume (subgenus Prunus, section Armeniaca) and P. ussuriensis (subgenus Prunus, section Prunus) with species in subgenus Cerasus section Cerasus. A few seeds resulted from these crosses; however, seeds were only produced when section Cerasus species served as the seed parent, which makes it more likely that these seedlings are the result of open pollination (contamination) by pollen from nearby and abundant specimens of the same section rather than true wide hybrids. We will continue to investigate the possibility of hybrids between sections and subgenera to combine traits such as evergreen foliage, disease resistance, and superior flower qualities.

Ploidy differences in plants can also contribute to barriers to interspecific hybridization. The basic chromosome number for most Prunus species is $\mathrm{n}=8$ (Darlington and Wylie, 1955). With the exception of P. maackii and members of the section Laurocerasus, the taxa used in this study were all diploid. Crosses between P. maackii $(4 \times)$ and the diploid taxa resulted in confirmed triploid plants (Pooler et al., 2012).

We have used SSR markers as a reliable and straightforward method to determine or verify the parentage of suspected hybrids. By verifying these hybrids, this study shows how relatively easy it is to broaden the genetic base of ornamental flowering cherries by hybridizing within section Cerasus. These markers will also be useful to verify the rarer hybrids between sections or subgenera in Prunus. By extension, in demonstrating how readily diverse flowering cherry taxa can be hybridized to broaden the genetic base, the results of this study also emphasize the importance of maintaining and expanding the pool of available Prunus genetic resources in the United States to create these new hybrids. 


\section{Literature Cited}

Bliss, F.A., S. Arulsekar, M.R. Foolad, V. Becerra, A.M. Gillen, M.L. Warburton, A.M. Dandekar, G.M. Kocsisne, and K.K. Mydin. 2002. An expanded genetic linkage map of Prunus based on an interspecific cross between almond and peach. Genome 45:520-529.

Bortiri, E., S. Oh, F. Gao, and D. Potter. 2002. The phylogenetic utility of nucleotide sequences of sorbitol 6-phosphate dehydrogenase in Prunus (Rosaceae). Amer. J. Bot. 89:1697-1708.

Bortiri, E., S. Oh, J. Jiang, S. Baggett, A. Granger, C. Weeks, M. Buckingham, D. Potter, and D. Parfitt. 2001. Phylogeny and systematics of Prunus (Rosaceae) as determined by sequence analysis of ITS and the chloroplast trnL-trnF spacer DNA. Syst. Bot. 26:797-807.

Bortiri, E., B. Vanden Heuvel, and D. Potter. 2006. Phylogenetic analysis of morphology in Prunus reveals extensive homoplasy. Plant Syst. Evol. 259:53-71.

Cantini, C., A.F. Iezzoni, W.F. Lamboy, M. Boritzki, and D. Struss. 2001. DNA fingerprinting of tetraploid cherry germplasm using simple sequence repeats. J. Amer. Soc. Hort. Sci. 126:205-209.

Cipriani, G., G. Lot, W.G. Huang, M.T. Marrazzo, E. Peterlunger, and R. Testolin. 1999. AC/GT and AG/CT microsatellite repeats in peach [Prunus persica (L) Batsch]: Isolation, characterization and crossspecies amplification in Prunus. Theor. Appl. Genet. 99:65-72.

Darlington, C.D. and A.P. Wylie. 1955. Chromosome atlas of flowering plants. George Allen and Unwin, London, UK.

Faust, M. and D. Suranyi. 1997. Origin and dissemination of cherry. Hort. Rev. 19:263-317.

Flower Association of Japan. 1982. Manual of Japanese flowering cherries. Flower Assn. of Japan, Tokyo, Japan.

Ingram, C. 1970. A garden of memories. H.F. and G. Witherby, London, UK.

Jefferson, R.M. and K.K. Wain. 1984. The nomenclature of cultivated Japanese flowering cherries (Prunus): The sato-zakura group. U.S. Dept. Agr., U.S. Natl. Arboretum Contribution No. 5.

Jung, S., M. Staton, T. Lee, A. Blenda, R. Svancara, A. Abbott, and D. Main. 2008. GDR (Genome Database for Rosaceae): Integrated web-database for Rosaceae genomics and genetics data. Nucleic Acids Res. 36:D1034-D1040.

Krussmann, G. 1984. Manual of cultivated broad-leaved trees and shrubs. Vol. II, Pru-Z. Timber Press, Portland, OR.

Kuitert, W. 1999. Japanese flowering cherries. Timber Press, Portland, OR. Lee, S. and J. Wen. 2001. A phylogenetic analysis of Prunus and the Amygdaloideae (Rosaceae) using ITS sequences of nuclear ribosomal DNA. Amer. J. Bot. 88:150-160.
Liu, X., J. Wen, Z. Nie, G. Johnson, Z. Liang, and Z. Chang. 2012. Polyphyly of the Padus group of Prunus (Rosaceae) and the evolution of biogeographic disjunctions between eastern Asia and eastern North America. J. Plant Res. doi: 10.1007/s10265-012-0535-1.

Ma, H., R. Olsen, M. Kramer, and M. Pooler. 2009. Evaluation of flowering cherry species, hybrids, and cultivars using simple sequence repeat markers. J. Amer. Soc. Hort. Sci. 134:435-444.

Mnejja, M., J. Garcia-Mas, W. Howad, and P. Arus. 2005. Development and transportability across Prunus species of 42 polymorphic almond microsatellites. Mol. Ecol. Notes 5:531-535.

Notcutt, R.C. and R.F. Notcutt. 1935. Flowering cherries. J. Royal Hort. Soc. 60:354-362.

Ohta, S., T. Yamamota, C. Nishitani, T. Katsuki, H. Iketani, and M. Omura. 2007. Phylogenetic relationships among Japanese flowering cherries (Prunus subgenus Cerasus) based on nucleotide sequences of chloroplast DNA. Plant Syst. Evol. 263:209-225.

Olsen, R.T. and A.T. Whittemore. 2009. Validation of the hybrid flowering cherry Prunus Xincam (Rosaceae). Novon 19:490-493.

Pooler, M., H. Ma, and D. Kidwell-Slak. 2012. Interploid hybridizations in ornamental cherries using Prunus maackii. J. Environ. Hort. 30:89-92.

Rehder, A. 1940. Manual of cultivated trees and shrubs hardy in North America. 2nd Ed. Dioscorides Press, Portland, OR.

Sosinski, B., M. Gannavarapu, L.D. Hager, L.E. Beck, G.J. King, C.D. Ryder, S. Rajapakse, W.V. Baird, R.E. Ballard, and A.G. Abbott. 2000. Characterization of microsatellite markers in peach [Prunus persica (L.) Batsch]. Theor. Appl. Genet. 101:421-428.

Steiner, J.J., C.J. Polemba, R.G. Fjellstrom, and L.F. Elliott. 1995. A rapid one-tube genomic DNA extraction process for PCR and RAPD analyses. Nucleic Acids Res. 23:2569-2570.

Tsuruta, M., H. Ishikawa, S. Kato, and Y. Mukai. 2012. Estimation of the hybridization range between cv. somei-yoshino and wild flowering cherries, and the factors influencing inter-specific gene flow. J. Jpn. For. Soc. 94:229-235.

U.S. Department of Agriculture. 2010. 2007 Census of horticultural specialties (2009). 11 Dec. 2012. <http://www.agcensus.usda.gov/ Publications/2007/Online_Highlights/Census_of_Horticulture_ Specialties/hortic_1_020_021.pdf $>$.

U.S. Department of Agriculture. 2012a. GRIN species records of Prunus subg. Cerasus. 11 Dec. 2012. <http://www.ars-grin.gov/ cgi-bin/npgs/html/splist.pl?20151>.

U.S. Department of Agriculture. 2012b. USDA plant hardiness zone map. 4 Feb. 2013. <http://planthardiness.ars.usda.gov>. 